\title{
Graham Stanton
}

\section{Studies in Matthew and Early Christianity}

\author{
Ed. by Markus Bockmuehl and David Lincicum
}

[Studien zu Matthäus und dem frühen Christentum.]

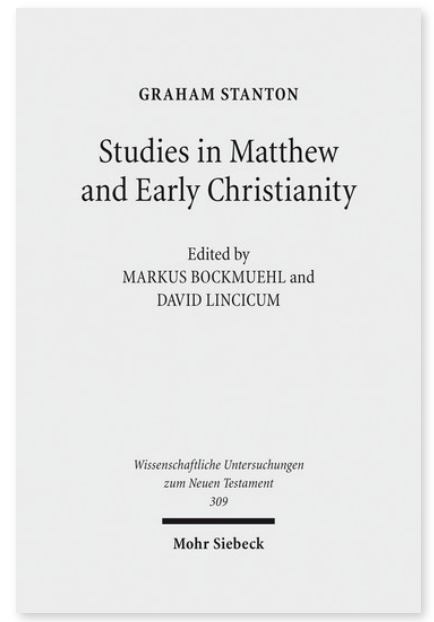

2013. XI, 483 Seiten. WUNT I 309

ISBN 978-3-16-152544-5

DOI 10.1628/978-3-16-152544-5

eBook PDF 189,00€

ISBN 978-3-16-152543-8

Leinen $189,00 €$
Veröffentlicht auf Englisch.

Im Laufe seiner herausragenden Karriere hat der kürzlich verstorbene Graham Stanton, Lady Margaret's Professor für Theologie an der Universität Cambridge, zahlreiche Forschungsbeiträge über das Neue Testament und frühchristliche Themen geschrieben. Dieser Band enthält sechsundzwanzig Aufsätze, einschließlich eines bisher unveröffentlichten, und umfasst einige seiner bekanntesten Beiträge zur Forschung. Gegen Ende seines Lebens schrieb Stanton ein Buch über Justin den Märtyrer im Kontext des frühen christlich-jüdischen Dialogs. Obwohl er das eigentliche Projekt nicht vor seinem Tod abschließen konnte, veröffentlichte er einige Vorab-Studien. Diese sind in diesem Band enthalten, ebenso wie ein unveröffentlichter Aufsatz, der 'Justins Ansichten über Märtyrertum und Selbstmord' untersucht.

Inhaltsübersicht

Introduction Chapter 1: The Origin and Purpose of Matthew's Gospel: Matthean Scholarship from 1945-1980 Chapter 2:

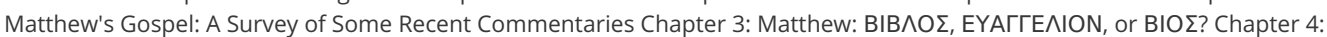
The Communities of Matthew Chapter 5: Revisiting Matthew's Communities Chapter 6: Ministry in Matthean Christianity Chapter 7: The Early Reception of Matthew's Gospel: New Evidence from Papyri? Chapter 8: Presuppositions in New Testament Criticism Chapter 9: Form Criticism Revisited Chapter 10: The Gospel Traditions and Early Christological Reflection Chapter 11: On the Christology of Q Chapter 12: Incarnational Christology in the New Testament Chapter 13: Messianism and Christology: Mark, Matthew, Luke and Acts Chapter 14: Rudolf Bultmann: Jesus and the Word Chapter 15: Stephen in Lucan Perspective Chapter 16: Paul's Gospel Chapter 17: The Law of Moses and the Law of Christ: Galatians 3:1-6:2 Chapter 18: What is the Law of Christ? Chapter 19: Interpreting the New Testament Today Chapter 20: The Two Parousias of Christ: Justin Martyr and Matthew Chapter 21: 'God-Fearers': Neglected Evidence in Justin Martyr's Dialogue with Trypho Chapter 22: Justin Martyr's Dialogue with Trypho: 'Group Boundaries', 'Proselytes' and 'God-Fearers' Chapter 23: The Spirit in the Writings of Justin Martyr Chapter 24: Justin on Martyrdom and Suicide Chapter 25: Aspects of Early Christian and Jewish Worship: Pliny and the Kerygma Petrou Chapter 26: Jewish Christian Elements in the Pseudo-Clementine Writings

Graham Stanton (1940-2009) 1969 PhD from Cambridge; 1970-98 Professor at King's College London; 1998-2009 Lady Margaret's Professor of Divinity, University of Cambridge and Fellow of Fitzwilliam College.

Markus Bockmuehl Born 1961; 1987 PhD from Cambridge; since 2007 Professor of Biblical and Early Christian Studies, University of Oxford and Fellow of Keble College.

David Lincicum Born 1979; since 2015 Associate Professor of New Testament and Early Christian Studies at the University of Notre Dame, USA.

Jetzt bestellen:

https://mohrsiebeck.com/buch/studies-in-matthew-and-early-christianity-9783161525445?no_cache=1 order@mohrsiebeck.com

Telefon: +49 (0)7071-923-17

Telefax: +49 (0)7071-51104 